\title{
Job control and demands, work-life balance and wellbeing among self- employed men and women in Europe
}

\author{
Mikael Nordenmark ${ }^{1 \star}$, Stig Vinberg ${ }^{1}$ and Mattias $\operatorname{Strandh}^{2,3}$ \\ ${ }^{1}$ Department of Health Sciences, Mid Sweden University, Östersund, Sweden; \\ ${ }^{2}$ Department of Sociology, Umeå University, Umeå, Sweden; ${ }^{3}$ Centre for Applied \\ Psychological Research, School of Psychology, Social Work and Social Policy, \\ University of South Australia, Adelaide, Australia
}

\begin{abstract}
Self-employed persons and their enterprises are regarded as important to the economy for their contribution to economic development. However, an understanding of the relationship between the psychosocial working conditions, the work-life balance and outcomes, such as health and wellbeing among the self-employed and micro-enterprise is limited. The main aim of this article is to study the relationships between control and demands at work, the work-life balance and wellbeing among self-employed men and women. Data were obtained from the European Social Survey (ESS) programme 2004, which is an interview survey conducted in 26 European countries ( $n=15789$ ). Wellbeing is measured by the WHO-Five Wellbeing Index and work-life balance is measured by an index consisting of two questions on work-life balance/conflict. The results show that men and women who are self-employed experience a lower level of work-life balance than those employed and this result is found more in men than women. When job control and demands are held constant for the self-employed and the employed, self-employed women experience a significantly higher level of work-life balance than do employed women, but self-employed men experience a similar level of work-life balance as do employed men. Self-employed women have a slightly higher level of wellbeing than do employed women and the difference between the selfemployed and the employed men is non-significant. When controlling for the level of job control, the relationship between self-employment and wellbeing is non-significant among women and is significantly negative among men. The results of this study confirm that the psychosocial working conditions are important because demands and control in work influence work-life balance and wellbeing among self-employed men and women.
\end{abstract}

Keywords: Fob control; job demands; Europe; gender; self-employment; wellbeing; work-life balance

*Correspondence to: Mikael Nordenmark, Department of Health Sciences, Mid Sweden University, SE-831 25 Östersund, Sweden. Email: mikael.nordenmark@miun.se 
Many European political initiatives present self-employment and entrepreneurship as a desirable career choice and note various benefits associated with it, for example, unlimited amounts of decision authority, broader utilisation, greater flexibility and the development of skills (European Commission, 2004; Verheul \& Wennekers, 2002). Furthermore, selfemployed persons and micro-enterprises (those with fewer than 10 employees) are regarded as important to the economy for their contribution to economic development. This is evident in the large number of jobs they provide and also their ability to create new ones (Davidsson, 2005; Fölster, 2000; Henrekson \& Stenkula, 2009).

In light of an increasing emphasis on self-employment and micro-enterprises, a growing body of research has focused on the determinants for pursuing selfemployment (Dolinsky \& Caputo, 2003). This research, however, has largely focused on the positive factors that attract people to self-employment and less on the consequences or outcomes of selfemployment (Dolinsky \& Caputo, 2003). There is a limited understanding about the relationships between the psychosocial working conditions, the work-life balance and outcomes, such as health and wellbeing among the self-employed (Lindström, Schrey, Ahonen, \& Kaleva, 2000; Vinberg, 2006; Volery \& Pullich, 2009). In addition, several studies on self-employment suffer from limitations, such as having small and limited samples as well as failing to analyse men and women separately.

The purpose of this article is to aid in understanding of the relationships between control and demands at work, the work-life balance and wellbeing among self-employed men and women as compared to regular employees. In this study, a self-employed person is defined as a person working in their own businesseither as a sole proprietor or in a business with a maximum of 10 employees. Data were obtained from the ESS programme, and the sample used in this study from 26 countries is fairly representative of the European scenario.

\section{PSYCHOSOCIAL WORKING CONDITIONS, WELLBEING AND THE WORK-LIFE BALANCE}

One of the leading models describing psychosocial job characteristics and their relationship to health and wellbeing is the job demand-control model (Karasek \& Theorell, 1990; Theorell \& Karasek, 1996). The central tenet of this model is that situational workplace characteristics, such as psychological job demands and levels of job control interact and affect the worker's foundations for learning, personal development and psychological strain. Psychological job demands refer to those factors that are related to time pressure, mental load and coordination responsibilities. Job control (or decision latitude) comprises two components: decision authority and skill discretion. Decision authority is a socially agreed upon form of control over job performance that allows the employee to decide how and when a job task is completed. Skill discretion refers to control over the use of the employee's initiative and skills on the job. A high level of control over the work situation, manageable work demands and extensive social support are crucial factors an employee needs to be able to experience a high level of job 
satisfaction and wellbeing (de Lange, Taris, Kompier, Houtman, \& Bongers, 2003; Karasek \& Theorell, 1990; Sundin 2009).

The levels of control and demands on the job are also shown to strongly influence work-life balance. High demands at work increase the risk of experiencing work-family conflicts (Chung, 2011; Fagan \& Walthery, 2011; Grönlund, 2007). However, research on the influence of high levels of control and flexibility at work show varying results. Some studies note that increasing levels of flexibility and control enhance the combination of work and family life, but other studies indicate that a high level of flexibility and control at work has negative effects on work-family balance (Fagan \& Walthery, 2011; Grönlund, 2004). The latter might be explained by the fact that a high level of control and flexibility at work requires the individual to be accessible at all times - they must be on call during unexpected private and family matters. Work and private matters tend to conflict, which can be perceived as stressful and negative to work-life balance (Allvin, Aronsson, Hagström, Johansson, \& Lundberg, 2004; Grönlund, 2004; Jonsson, 2007).

In comparing the levels of wellbeing and work-life balance among selfemployed men and women with those of male and female employees, there are, on the one hand, reasons to believe that the levels observed should be higher for the self-employed than those observed for the employed; however, there are, on the other hand, also reasons to believe that the levels observed should be lower for the self-employed than those observed for the employed. Various hypotheses exist concerning these possible differences between men and women.

Self-employment and psychosocial working conditions in micro-enterprises often mean close relationships, flexibility and control: these factors can facilitate a balance between work and family responsibilities, reduce stress and promote good health. Several studies show that the selfemployed have very high decision authority, control how work is organised and control how resources are distributed at their workplace, as they often own their own enterprise (Hundley, 2001; Stephan \& Roesler, 2010). Research has found that the self-employed have higher levels of job control concerning autonomy, discretion and opportunities for skillutilisation than employees (Hundley, 2001; Stephan \& Roesler, 2010).

Conversely, most research on the characteristics of the self-employed finds that they report higher job demands and a higher workload than do employees (Stephan \& Roesler, 2010). Working conditions in micro-enterprises often entail working long, irregular and arduous hours with a great deal of time pressure and heavy workloads (Lindström et al., 2000). In a Swedish study of small-scale entrepreneurs (Gunnarsson, 2010), results show that long working hours were more common among entrepreneurs than among employees. Some maintain that leadership is authoritarian and working conditions are unsatisfactory with a high risk of injury and poor physical working environments (Gunnarsson, 2010; Wilkinson, 1999). These factors might have a negative influence on the level of wellbeing and work-life balance, and this should be true particularly for women, who often carry the main responsibility of maintaining the household 
and child care though they work fulltime (Nordenmark, 2004a, b; Parasuraman \& Simmers, 2001).

The aforementioned contradictions between working conditions and the possible implications for the level of wellbeing among the self-employed are also reflected in the relatively few empirical findings concerning wellbeing and divergent health outcomes among the self-employed (Dolinsky \& Caputo, 2003; Stephan \& Roesler, 2010).

Studies report higher levels of wellbeing, including fewer diagnosed mental and anxiety disorders among the selfemployed when compared to employees. Studies supporting this view show that health-related absenteeism figures in micro-enterprises are much lower than in larger enterprises (BornbergerDankvardt, Ohlson, \& Westerholm, 2003; Lindström et al., 2000; Vinberg, 2006). A possible explanation for these differences in health-related absenteeism is that social control is greater in microenterprises; therefore, it is more difficult to take time off from work (Bornberger et al., 2003). However, another explanation is that work content and respectful leadership are more developed in micro firms, which promote good health (Eakin, Lamm, \& Limborg, 2000). Furthermore, in empirical findings from a national representative sample, when compared to employees, the selfemployed showed significantly lower overall somatic and mental morbidity, lower blood pressure, as well as higher wellbeing and more favourable health indicators than did employees (Stephan \& Roesler, 2010).

However, although research shows that the self-employed are more satisfied with their work than the employees, there is evidence that they do not feel as well physically as do their employee counterparts (Benavides, Benach, Diez-Roux, \& Roman, 2000; Blanchflower, 2004; Bradley \& Roberts, 2004). In a Canadian study, the self-employed experienced more psychosomatic health problems than salaried workers did (Jamal, 1997), and a European study showed that the self-employed reported high percentages of stress, fatigue and muscular pain (Benavides et al., 2000). There are also studies that found no health differences between the self-employed and the employed. In a Swedish study, employees who became self-employed were more satisfied with their jobs, but no differences in self-rated health indicators were found between the self-employed and employees (Andersson, 2006). Finally, in a study of small-scale entrepreneurs over a 5-year period, a higher proportion of female entrepreneurs were more likely to experience improved health when compared with the male entrepreneurs (Gunnarsson, 2010).

With only a few studies that have analysed the level of wellbeing among the self-employed, there are even less that have measured the level of work-life balance in this group. As greater numbers of women set up their own businesses, the challenge of balancing two major adult roles can become a critical issue. Bernin (2002), in a study of managers' working conditions and health status, found that women reported higher psychological demands and intellectual discretion than did other professional groups. The study also showed that female managers employed coping behaviour that might increase the risk of illness and that they encountered greater difficulties in relaxing outside of work 
when compared to male managers. This result corresponds with results that indicate that many female business leaders identify the stress of balancing work and family and the inter-role conflict that this creates as one of their biggest problems (Harte, 1996). However, women can also be attracted to the potential benefits of self-employment that include a perceived increase in flexibility and a greater ability to balance the rewards and demands of career and family (Rogers, 1998).

The general conclusion is that the current knowledge concerning the differences between self-employed men and women's work-life balance and wellbeing and wage earners is insufficient (Benavides et al., 2000; Bornberger et al., 2003; Gunnarsson, 2010; Vinberg, 2006). Furthermore, the relatively few studies on the relationships between control and demands at work, work-life balance and wellbeing among selfemployed men and women show varying and sometimes contradicting results. Some studies note that the self-employed often experience flexible working conditions and a high level of control over the work situation that can facilitate the reconciliation of work and private life obligations and promote good health. But, there are also studies that highlight the long and irregular working hours and arduous working conditions often found in self-employment that can produce stress and increase the risk of experiencing work-life conflicts. In addition, several studies on self-employment suffer from limitations, such as small and specific samples and most have not considered men and women separately. All of this motivates additional research on the relationships between control and demands at work, the work-life balance and wellbeing among self-employed men and women.

\section{AIM AND RESEARCH QUESTIONS}

The main aim of this article is to study the relationships between control and demands at work, work-life balance and wellbeing among self-employed men and women. This is done by analysing the following research questions:

- Do self-employed individuals experience a higher or a lower level of work-life balance and wellbeing than experienced by the employed?

- How does the level of control and demands at work influence the level of the work-life balance among the selfemployed?

- How does the level of control and demands at work influence levels of wellbeing among the self-employed?

- Are there gender differences among self-employed individuals regarding the relationships between the employment type, control and demands at work, the work-life balance and wellbeing?

\section{DATA AND VARIABLES}

The data used for this analysis are drawn from the 2004 wave of the European Social Survey (ESS) programme. ESS is a yearly comparative interview survey currently conducted in 30 European countries. The survey is in all countries based on nationally representative random samples and conducted using face to face interviews. It includes thematic sections that appear cyclically across the survey's waves. In 2004, ESS was 
conducted in 26 countries, indicating that most parts of Europe are represented. The average response rate was 61.5 percent with no country having a lower response rate than 43.6 percent (France). The 2004 wave contains the in-depth theme, "Family, work and wellbeing," that includes a number of questions that are relevant to this study. This section focuses on the relationship between work, family and wellbeing, as well as on the effects of changes in working life and family life to individuals' wellbeing. The data set includes questions regarding the respondent's and his or her partner's labour market status (including self-employment) and the size of the company (number of employees) that employs them. A self-employed person, in this article, is defined as self-employed with a maximum of 10 employees. The analysis is based on 15,789 respondents who were identified as either employed $(n=13,408) \quad$ or self-employed $\quad(n=$ $2,381)$. Other core independent and dependent variables include the following: attitude towards gender, working conditions, household conditions, measures of work-life balance and subjective wellbeing.

The dependent variable for wellbeing used in this study is measured by the WHO-Five Wellbeing Index (Löwe et al., 2004) that includes questions about whether during the last 2 weeks, the respondents have felt cheerful and in good spirits, calm and relaxed, active and vigorous, have woken up feeling fresh and rested and whether their daily lives have been filled with things that interest them. Confirmatory factor analysis showed a one-factor structure in our data and Cronbach's $\alpha$ of the five-item scale was 0.85 . The response alternatives vary in six steps from "at no time" to "all of the time," and have been summed to form an additive index ranging from 0 to 25; a higher score indicates a higher level of wellbeing.

Work-life balance is measured by two questions that ask the respondents to what degree their work life conflicts with their private life: "How often do you keep worrying about work problems when you are not working?" "How often do you feel too tired after work to enjoy the things you would like to do at home?" The variables represent one factor in a confirmatory factor analysis but Cronbach's $\alpha$ is somewhat weak at 0.53 . The response alternatives vary across five steps from "never" to "always" and have been summed to form an additive index ranging from 0 to 8 ; a higher score indicates a higher level of work-life balance. The relatively low Cronbach's $\alpha$ indicates that the results regarding work-life balance have to be interpreted with some caution.

Independent variables are measured as follows: the employment status of the respondent is measured by the question: "In your main job are/were you an employee or self-employed?" If the respondent answered self-employed, an additional question was asked: "How many employees (if any) do/did you have?" The level of control at work is measured by the following questions: "How much does the management at your job allow/allowed you to a) decide how your daily work is/was organised? b) influence policy decisions about the activities of the organisation? c) choose or change your pace of work?" The response alternatives range from 0 (have/ had no influence) to 10 (have/had complete control). High scores indicate high 
levels of control. Unfortunately, some questions included in the ESS that had been used in earlier studies as measures of the level of demands at work have not been addressed to the self-employed. Therefore, the indicators of job demands in this study are weekly work hours (logarithmic [work hours Zscore] and squared [Zwork hours ${ }^{\star \star} 2$ ] in the multivariate analyses), and the question about how often their job involves a) working evenings or nights? b) having to work overtime at short notice ( 1 - never to $7-$ every day)? c) working on weekends (1never to 5-every week)? High scores indicate high demands.

The multivariate analyses also control for background characteristics that have been previously shown or are assumed to be relevant to the levels of work-life balance and wellbeing. These include the following: gender, age (logarithmic [ageZscore] and squared [ZAge ${ }^{\star \star 2}$ ] in the multivariate analyses), civil status (married/cohabiting or single) and the occurrence of children living at home.

Bivariate correlations and block wise linear regression were used to analyse relationships between the dependent variables, wellbeing and work-life balance, and the independent variables measuring employment type, job control, job demands and background characteristics.

\section{RESULTS}

This section is structured as follows: the first table offers a descriptive view of the percentages and means on the dependent and independent variables among self-employed and employed men and women. This is followed by a pre- sentation of the correlations between the independent variables that measure levels of control and demands at work and the dependent variables that measure the levels of work-life balance and wellbeing among self-employed and employed men and women. The final section consists of an ordinary least squares (OLS)-regression that analyses the relationship between self-employment, the independent variables that measure the levels of control and demands at work and the dependent variables that measure the levels of the work-life balance and wellbeing when controlling for background characteristics. The variables are entered stepwise to investigate the role of control and demand in explaining the differences between the self-employed and the employed.

\section{Descriptive statistics}

Table I shows the number of employees (among self-employed), the level of worklife balance, the level of wellbeing, the level of control and demands at work and background characteristics among the employed and self-employed men and women. The measure of significance refers to the comparison between the self-employed and the employed. The last row in the table illustrates that approximately 15 percent of the working population in Europe is self-employed (11 percent among women and 19 percent among men), with a maximum of 10 employees. Most self-employed persons are sole-proprietors (61 percent). Only approximately 10 percent have more than five employees. The most noteworthy difference between self-employed men and women is that a larger proportion 
Table I. Descriptive data on employed and self-employed (percent and mean values).

\begin{tabular}{|c|c|c|c|c|c|c|}
\hline & \multicolumn{3}{|c|}{ Employed } & \multicolumn{3}{|c|}{ Self-employed } \\
\hline & All & Women & Men & All & Women & Men \\
\hline \multicolumn{7}{|l|}{ Number of employed } \\
\hline 0 (Sole proprietors) & & & & 61.0 & 71.1 & 56.2 \\
\hline 1 & & & & 11.6 & 10.5 & 12.0 \\
\hline $2-5$ & & & & 17.9 & 13.5 & 20.0 \\
\hline $6-10$ & & & & 9.5 & 4.9 & 11.7 \\
\hline Work-life balance & 4.51 & 4.41 & 4.59 & $3.95^{\star \star \star}$ & $4.04^{\star \star \star}$ & $3.91^{\star \star \star}$ \\
\hline Wellbeing & 15.64 & 15.25 & 16.00 & 15.82 & 15.58 & 15.95 \\
\hline \multicolumn{7}{|l|}{ Job control } \\
\hline Decide org of work & 5.93 & 5.89 & 5.97 & $9.04^{\star \star \star}$ & $8.96^{\star \star \star}$ & $9.08^{\star \star \star}$ \\
\hline Influence policy at work & 3.51 & 3.35 & 3.65 & $8.69^{\star \star \star}$ & $8.45^{\star \star \star}$ & $8.82^{\star \star \star}$ \\
\hline Choose pace of work & 5.62 & 5.54 & 5.70 & $8.95^{\star \star \star}$ & $8.88^{\star \star \star}$ & $9.00^{\star \star \star}$ \\
\hline \multicolumn{7}{|l|}{ Job demands } \\
\hline Work hours & 38.89 & 34.86 & 42.77 & $46.24^{\star \star \star}$ & $38.88^{\star \star \star}$ & $49.83^{\star \star \star}$ \\
\hline Working weekends & 2.44 & 2.32 & 2.56 & $3.53^{\star \star \star}$ & $3.33^{\star \star \star}$ & $3.62^{\star \star \star}$ \\
\hline Working evenings & 2.72 & 2.47 & 2.95 & $3.57^{\star \star \star}$ & $3.12^{\star \star \star}$ & $3.78^{\star \star \star}$ \\
\hline Overtime at short notice & 2.80 & 2.49 & 3.09 & $3.33^{\star \star \star}$ & 2.60 & $3.67^{\star \star \star}$ \\
\hline \multicolumn{7}{|l|}{ Background } \\
\hline Men & 50.8 & & & $66.8^{\star \star \star}$ & & \\
\hline Age & 39.95 & 39.93 & 39.98 & $44.22^{\star \star \star}$ & 44.66 & 44.01 \\
\hline Cohabiting/married & 69.1 & 68.0 & 70.1 & $77.2^{\star \star \star}$ & $80.4^{\star \star \star}$ & $75.6^{\star \star \star}$ \\
\hline Children & 53.0 & 56.1 & 49.9 & $58.2^{\star \star \star}$ & $64.6^{\star \star \star}$ & $55.0^{\star \star \star}$ \\
\hline $\mathrm{N}$ & $\begin{array}{l}13408 \\
(84.9 \%)\end{array}$ & $\begin{array}{l}6592 \\
(89.3 \%)\end{array}$ & $\begin{array}{l}6811 \\
(81.1 \%)\end{array}$ & $\begin{array}{l}2381 \\
(15.1 \%)\end{array}$ & $\begin{array}{l}789 \\
(10.7 \%)\end{array}$ & $\begin{array}{l}1591 \\
(18.9 \%)\end{array}$ \\
\hline
\end{tabular}

${ }^{\star \star \star} p=0.001^{\star \star} p=0.01{ }^{\star} p=0.05$.

of self-employed women are sole proprietors. Both women and men who are selfemployed experience a significantly lower level of work-life balance when compared to employed men and women. There are no significant differences in the level of wellbeing between employees and the self-employed; however, the higher score (indicating a higher level of wellbeing) among self-employed women is borderline significant.

The variables measuring the level of control and demands at work indicate that self-employed women and men have more control and experience higher demands at work than women and men who are employed. Self-employed men and women have more capacity to decide how to organise their work, influence the policy at work and choose the pace of their work. The findings regarding demands at work show that the selfemployed, on average, work 46 hours per week, compared to 39 hours per week for the employed. The self-employed also work on weekends and evenings more frequently, and more often work overtime at short notice than do the employed. However, self-employed women do not work overtime at short notice significantly more often than women who are employed. All variables measuring 
demands at work indicate that men in general experience higher demands than women. For example, self-employed men work, on average, 50 hours per week, while self-employed women work, on average, 39 hours per week.

An analysis of the background characteristics shows that 67 percent of the self-employed are men, which is a significantly higher proportion than the percentage of men among the employed. The mean age is somewhat higher among the self-employed than it is among the employed with a mean age of 44 years for the self-employed compared to a mean age of 40 years for the employed. When compared with the employed, it is more common for both self-employed men and women to be cohabitants or married and living together with children than it is for the employed.

\section{Correlations among the employed and the self-employed}

Before analysing how control and demands at work influence the relationship between employment type (employee/ self-employed) and the dependent variables, work-life balance and wellbeing, we will examine the main independent variables to show how they are related to the work-life balance and wellbeing within the two groups. Table II shows how the variables measuring the level of control and demands at work are related to work-life balance and wellbeing among the employed and the self-employed.

In analysing the work-life balance, one can see that among the employed, all variables measuring the level of job control indicate that a high level of control is correlated to a lower level of work-life balance. In addition, high job demands decrease work-life balance. These results hold for both women and men. In our analysis of the selfemployed, we observe that the variables measuring job control do not appear to be as important for work-life balance as it is among the employed. It is only the capacity to influence work policies that has a significant relationship to work-life balance, and this is seen at a weaker level than what is found in the employed. A partial explanation for this is that these variables have a smaller variance among the self-employed. Most self-employed men and women have high levels of control at work and very few have low levels of control (analyses not shown). Conversely, the variables that indicate job demands at work do have similar and possibly stronger, negative effects among the self-employed than they have among the employed.

Our analysis of wellbeing shows that job control has a generally positive relationship to wellbeing in employees. A high level of control is related to a high level of wellbeing among both male and female employees. This positive relationship between control at work and wellbeing is also found for selfemployed men, but it does not appear for self-employed women. The coefficients for the control variables are consistently low and insignificant for self-employed women. For the job demand variables, we observe that work hours are positively related to wellbeing among female employees but not among male employees. Work hours are, however, the only demand variable that is significantly related to wellbeing among employed women; it is a relationship that 
Table II. Work-life balance and wellbeing by job control and job demands among employed and self-employed women and men (Pearson).

\begin{tabular}{|c|c|c|c|c|c|c|}
\hline & \multicolumn{3}{|c|}{ Work-life balance } & \multicolumn{3}{|c|}{ Wellbeing } \\
\hline & All & Women & Men & All & Women & Men \\
\hline \multicolumn{7}{|l|}{ Employed } \\
\hline \multicolumn{7}{|l|}{ Job control } \\
\hline Decide org of work & $-0.133^{\star \star \star}$ & $-0.122^{\star \star \star}$ & $-0.146^{\star \star \star}$ & $0.049^{\star \star \star}$ & $0.042^{\star \star}$ & $0.056^{\star \star \star}$ \\
\hline $\begin{array}{l}\text { Influence policy at } \\
\text { work }\end{array}$ & $-0.157^{\star \star \star}$ & $-0.155^{\star \star \star}$ & $-0.164^{\star \star \star}$ & $0.072^{\star \star \star}$ & $0.058^{\star \star \star}$ & $0.080^{\star \star \star}$ \\
\hline Choose pace of work & $-0.114^{\star \star \star}$ & $-0.109^{\star \star \star}$ & $-0.123^{\star \star \star}$ & $0.050^{\star \star \star}$ & $0.045^{\star \star \star}$ & $0.051^{\star \star \star}$ \\
\hline \multicolumn{7}{|l|}{ Job demands } \\
\hline Work hours & $-0.169^{\star \star \star}$ & $-0.233^{\star \star \star}$ & $-0.157^{\star \star \star}$ & $0.051^{\star \star \star}$ & $0.036^{\star \star}$ & 0.013 \\
\hline Working weekends & $-0.184^{\star \star \star}$ & $-0.194^{\star \star \star}$ & $-0.185^{\star \star \star}$ & $-0.031^{\star \star}$ & -0.022 & $-0.053^{\star \star \star}$ \\
\hline Working evenings & $-0.178^{\star \star \star}$ & $-0.199^{\star \star \star}$ & $-0.174^{\star \star \star}$ & -0.018 & -0.010 & $-0.043^{\star \star \star}$ \\
\hline $\begin{array}{l}\text { Overtime at short } \\
\text { notice }\end{array}$ & $-0.268^{\star \star \star}$ & $-0.281^{\star \star \star}$ & $-0.282^{\star \star \star}$ & -0.008 & -0.005 & $-0.035^{\star \star}$ \\
\hline \multicolumn{7}{|l|}{ Self-employed } \\
\hline \multicolumn{7}{|l|}{ Job control } \\
\hline Decide org of work & -0.001 & 0.014 & -0.007 & $0.046^{\star}$ & -0.048 & $0.093^{\star \star \star}$ \\
\hline $\begin{array}{l}\text { Influence policy at } \\
\text { work }\end{array}$ & $-0.082^{\star \star \star}$ & $-0.109^{\star \star}$ & $-0.066^{\star}$ & $0.062^{\star \star}$ & 0.006 & $0.095^{\star \star \star}$ \\
\hline Choose pace of work & 0.002 & 0.056 & -0.022 & $0.058^{\star \star}$ & 0.024 & $0.074^{\star \star}$ \\
\hline \multicolumn{7}{|l|}{ Job demands } \\
\hline Work hours & $-0.322^{\star \star \star}$ & $-0.324^{\star \star \star}$ & $-0.325^{\star \star \star}$ & 0.000 & -0.047 & 0.016 \\
\hline Working weekends & $-0.283^{\star \star \star}$ & $-0.323^{\star \star \star}$ & $-0.260^{\star \star \star}$ & $-0.062^{\star \star}$ & $-0.117^{\star \star}$ & -0.040 \\
\hline Working evenings & $-0.236^{\star \star \star}$ & $-0.142^{\star \star \star}$ & $-0.277^{\star \star \star}$ & -0.026 & -0.054 & -0.022 \\
\hline $\begin{array}{l}\text { Overtime at short } \\
\text { notice }\end{array}$ & $-0.352^{\star \star \star}$ & $-0.299^{\star \star \star}$ & $-0.377^{\star \star \star}$ & $-0.070^{\star \star}$ & -0.016 & $-0.109^{\star \star \star}$ \\
\hline
\end{tabular}

$$
{ }^{\star \star \star} p<0.001{ }^{\star \star} p<0.01{ }^{\star} p<0.05
$$

might be related to a potentially stronger "healthy worker effect" in this group. The remaining job demand variables have significant negative relationships to wellbeing among employed men but not among employed women. Compared with the employed, we find only two significant relationships between the job demand variables and wellbeing among the self-employed: the variable "working weekends" is significantly negatively related to wellbeing in women, whereas "overtime at short notice" has the same relationship to wellbeing in men.

\section{Employment type, work-life balance} and wellbeing

The results so far suggest that the selfemployed experience a lower level of work-life balance but enjoy a somewhat similar level of wellbeing when compared to employees. The level of job control is substantially higher among the selfemployed and they also experience a higher level of demands at work. Furthermore, both the level of control and demands at work are in general negatively correlated with work-life balance. Job control is positively correlated with 
wellbeing, but job demands, to some extent, have a negative relationship to wellbeing.

The above might indicate that the level of work-life balance among the selfemployed should increase when controlling for demands and control at work. This would indicate that the low level of work-life balance among the selfemployed can be explained by their high levels of job control and demands in relation to the employed. The above results could also indicate that the wellbeing among the self-employed should decrease, particularly when controlling for the level of job control. This would indicate that the wellbeing among the self-employed should be lower than among the employed when controlling for the level of control at work.

These hypotheses are tested in Table III, which investigates the level of work-life balance and wellbeing among self-employed women and men when controlling for the level of control and demands at work and background characteristics. The results are based on analyses of women and men as a group; however, the values for self-employed men and self-employed women, from separate analyses of women and men, are shown within brackets (analyses and tables not shown). All models control for background characteristics, such as gender, age, civil status and having children.

Model 1 shows the bivariate values for the self-employed on the work-life balance scale and for self-employed men and women in brackets (generated from separate analyses of men and women). Model 1 confirms the result found in Table I: the self-employed experience a lower level of work-life balance than do the employed. The values from the separate analyses of women and men indicate that this is true for both men and women; however, the relationship is stronger among men.

Model 2 illustrates that the lower level of work-life balance among the self-employed can be explained, in part, by the higher level of control they experience at work. When controlling for variables measuring levels of job control, the coefficient among the self-employed changes from -0.583 to -0.165 . Consequently, in the separate analyses of women and men, the relationship among women is non-significant. The results for levels of control at work indicate that it is the possibility of influencing policy at work that has the strongest influence; however, the relationship between the possibility of choosing the pace of work and work-life balance is non-significant.

Model 3 shows that when controlling for job demands, the relationship between self-employment and work-life balance is non-significant for men and women combined. This indicates that the lower level of work-life balance among the self-employed, shown in Model 1, can be explained by their own higher levels of control and demands at work when compared to levels found in the employed. The coefficients from the separate analyses of women and men show that there is a significantly higher level of work-life balance among selfemployed women than among employed women when controlling for control and demands at work.

The results for the background variables show that men experience a higher level of work-life balance than do women. The higher the age, the higher is the level of work-life balance, but ZAge ${ }^{\star \star} 2$ indicates that the relationship is curvilinear. 
Table III. Linear regression. Work-life balance and wellbeing by the employment type, job control, job demands and background characteristics. B-coefficients.

\begin{tabular}{|c|c|c|c|c|c|c|}
\hline & \multicolumn{3}{|c|}{ Work-life balance } & \multicolumn{3}{|c|}{ Wellbeing } \\
\hline & Model 1 & Model 2 & Model 3 & Model 4 & Model 5 & Model 6 \\
\hline Constant & 4.306 & 4.700 & 5.445 & 14.779 & 14.261 & 14.872 \\
\hline Self-employed & $-0.583^{\star \star \star}$ & $-0.165^{\star \star}$ & 0.094 & 0.127 & $-0.405^{\star \star}$ & $-0.304^{\star}$ \\
\hline (Women) & $\left(-0.375^{\star \star \star}\right)$ & $(0.061)$ & $\left(0.417^{\star \star \star}\right)$ & $\left(0.434^{\star}\right)$ & $-0.072)$ & $(0.254)$ \\
\hline (Men) & $\left(-0.693^{\star \star \star}\right)$ & $\left(-0.300^{\star \star \star}\right)$ & $(0.123)$ & $(-0.025)$ & $\left(-0.866^{\star \star \star}\right)$ & $\left(-0.595^{\star \star \star}\right)$ \\
\hline \multicolumn{7}{|l|}{ Job control } \\
\hline Decide org of work & & $-0.023^{\star \star}$ & $-0.023^{\star \star \star}$ & & 0.011 & 0.010 \\
\hline Infl policy at work & & $-0.065^{\star \star \star}$ & $-0.048^{\star \star \star}$ & & $0.089^{\star \star \star}$ & $0.089^{\star \star \star}$ \\
\hline Choose pace of work & & -0.006 & -0.005 & & 0.024 & 0.023 \\
\hline \multicolumn{7}{|l|}{ Job demands } \\
\hline Work hours Zscore & & & $-0.247^{\star \star \star}$ & & & 0.135 \\
\hline ZWork hours ${ }^{\star \star 2}$ & & & 0.008 & & & $-0.058^{\star}$ \\
\hline Working weekends & & & $-0.126^{\star \star \star}$ & & & $-0.098^{\star \star}$ \\
\hline Working evenings & & & $-0.028^{\star \star}$ & & & -0.008 \\
\hline Overtime short notice & & & $-0.194^{\star \star \star}$ & & & $-0.088^{\star \star \star}$ \\
\hline \multicolumn{7}{|l|}{ Background } \\
\hline Men & $0.123^{\star \star \star}$ & $0.155^{\star \star \star}$ & $0.474^{\star \star \star}$ & $0.635^{\star \star \star}$ & $0.598^{\star \star \star}$ & $0.620^{\star \star \star}$ \\
\hline Age Zscore & $0.176^{\star \star \star}$ & $0.189^{\star \star \star}$ & $0.056^{\star}$ & $-0.156^{\star}$ & $-0.173^{\star}$ & $-0.171^{\star}$ \\
\hline ZAge $^{\star \star 2}$ & $0.398^{\star \star \star}$ & $0.348^{\star \star \star}$ & $0.263^{\star \star \star}$ & $0.419^{\star \star \star}$ & $0.491^{\star \star \star}$ & $0.472^{\star \star \star}$ \\
\hline Cohabiting/married & -0.024 & 0.009 & $-0.044^{\star \star \star}$ & $0.833^{\star \star \star}$ & $0.794^{\star \star \star}$ & $0.713^{\star \star \star}$ \\
\hline Children & 0.020 & 0.003 & -0.007 & $-0.572^{\star \star \star}$ & $-0.545^{\star \star \star}$ & $-0.480^{\star \star \star}$ \\
\hline$R^{2}$ & 0.025 & 0.046 & 0.151 & 0.015 & 0.021 & 0.022 \\
\hline
\end{tabular}

${ }^{\star \star \star} p<0.001{ }^{\star \star} p<0.01{ }^{\star} p<0.05$. 
The results from Model 3 indicate that cohabiting/married people have a lower level of work-life balance than do singles.

Observing wellbeing in Model 4, the level of wellbeing among the selfemployed does not differ significantly from the employed. However, separate analyses of women and men show that self-employed women experience a significantly higher level of wellbeing than do employed women.

When controlling for variables that measure the level of job control in Model 5, the relationship between selfemployment and wellbeing is significantly negative. The results from the separate analyses of women and men show that this relationship is true only among men, indicating that when the level of control at work is held constant, self-employed men have a lower level of wellbeing than do employed men. Again, it is the possibility of influencing policy at work that stands out among the variables indicating control at work.

The significantly low level of wellbeing among the self-employed in general, and among self-employed men in particular, remains at a similar level when controlling for the job demands in Model 6. The measure, work hours, has a curvilinear relationship to wellbeing, and working weekends and overtime at short notice have a negative relationship to wellbeing.

The results for the background characteristics show that men in general have a higher level of wellbeing than women. Age is negatively correlated with wellbeing and the variable ZAge ${ }^{\star \star} 2$ indicates that this correlation is curvilinear to some extent. Cohabiting/married people experience a significantly higher level of wellbeing than do singles; and people living with children have a lower level of wellbeing than do people living without children.

\section{CONCLUDING DISCUSSION}

The purpose of this study was to identify relationships between control and demands at work, work-life balance and wellbeing among self-employed women and men and to make comparisons with regular employees. Wellbeing among self-employed individuals working in micro-enterprises is a research area that is important, yet remains inadequately investigated. Improved wellbeing among the self-employed can be a resource for entrepreneurial behaviour and can contribute to better preconditions for these individuals' quality of life. This is a highly topical research area because selfemployment and micro-enterprises are important to regional and national development and because small business research to a high degree has focused on small- and medium-sized enterprises and entrepreneurship.

The results of this study show that most of the self-employed are sole-proprietors or those working in micro-enterprises with fewer than five employees, which is in line with other researches on the subject (e.g. Curran \& Blackburn, 2001; Davidsson, 2005). The fact that majority of the selfemployed are men, that a larger proportion of self-employed women are sole-proprietors and that the mean age is higher among the self-employed than it is among the employed is also in accordance with other studies (The Swedish Social Insurance Inspectorate, 2012).

Regarding the working conditions among the self-employed in relation to 
the employed, the results show that the self-employed have greater job control in that they, to a higher degree, can decide the organisation of their work, influence work policy and choose the pace of their work. This is in line with findings from previous studies (e.g. Gunnarsson, 2010; Hundley, 2001; Lindström et al., 2010). Conversely, they experience higher job demands and longer, more irregular working hours when compared with the employed. These results, indicating that the self-employed to a greater extent are exposed to higher demands at work as measured by the amount of work when compared with the employed, support the results from other studies (e.g. Gunnarsson, 2010).

The main aim of this study was, however, to analyse the influence of control and demands at work on worklife balance and wellbeing among selfemployed men and women. The results support the importance of control and demands at work for work-life balance and level of wellbeing. High levels of job control and job demands are negatively related to work-life balance. This supports the research finding that a high level of control and flexibility can have a negative influence on work-family balance (Chung, 2011; Fagan \& Walthery, 2011; Grönlund, 2004). A high level of control at work is generally beneficial for wellbeing, while to some extent, high level of demands at work has a negative relationship to wellbeing. In addition, these results support other studies presented in the introduction of this article (de Lange et al., 2003; Karasek \& Theorell, 1990; Sundin, 2009).

When comparing the self-employed with the employed, the former experience a lower level of work-life balance.
However, when controlling for levels of control and demands at work, the relationship between the employment type and work-life balance is non-significant. This indicates that the lower level of work-life balance among the selfemployed can be explained by the high level of control and high demands at work among the self-employed when compared to the employed. This also indicates that if the self-employed had the same relatively low level of control and demands in their work as do the employed, there would not be a difference between the self-employed and employees' level of work-life balance.

Study results from separate analyses of women and men indicate that both selfemployed men and women experience a lower level of work-life balance than do the employed, but this result is more prominent among men. Job control and demands have a similar influence on the relationship between the employment type and work-life balance among both men and women. However, because the B-coefficient for self-employed men is substantially lower than the Bcoefficient for self-employed women, from the start, the relationship between self-employment and work-life balance is non-significant among men and significantly positive among women when controlling for job control and demands. This indicates that when control and demands at work are held constant for the self-employed and the employed, self-employed women experience a significantly higher level of work-life balance than do employed women, and self-employed men experience a similar level of work-life balance as do employed men. 
When controlling only for background characteristics, there is no significant relationship between the employment type and wellbeing, indicating that wellbeing is at a similar level among the self-employed as it is among the employed. When controlling for the level of job control, the relationship between self-employment and wellbeing is significantly negative. This indicates that when holding the level of job control constant (particularly the possibility of influencing the work policy), the self-employed have a lower level of wellbeing than that found in the employed. Although the variables measuring job demands are significantly related to wellbeing, these variables do not appear to substantially influence the relationship between the employment type and wellbeing.

Analysing men and women separately and controlling only for background characteristics, one can see that selfemployed women have a higher level of wellbeing than employed women have and that the difference between selfemployed men and employed men is non-significant. Job control has a similar influence on the affiliation between the employment type and wellbeing among both men and women. However, when controlling for the level of job control, the relationship between self-employment and wellbeing is non-significant among women and significantly negative among men, which again is explained by the difference between women and men from the start. This indicates that if job control is observed at a similar level in the selfemployed as in the employed, self-employed men experience a lower level of wellbeing than employed men, and selfemployed women experience a similar level of wellbeing as employed women.
These results confirm that the psychosocial working conditions are important because demands and control in work affect work-life balance and wellbeing among the self-employed, and that selfemployed jobs can be seen as jobs with high job demands and high job control. A high level of job control is a primary indicator for the observed higher levels of wellbeing in self-employed women than those found for employed women and for the self-employed men not experiencing lower levels of wellbeing than employed men. When job control is observed at a similar level for the selfemployed as it is for the employed, the level of wellbeing is found to be lower among self-employed men, but it is found to be at a similar level among self-employed women when compared to the level found for employed men and women. The high level of job control among the self-employed does, however, have both risks and benefits. Whereas in terms of wellbeing, job control is an important factor in compensating the worker for the liabilities of selfemployment, it also contributes to lower levels of work-life balance among the self-employed.

This finding regarding job control as an important factor for both positive and negative outcomes in self-employment shows that it is a central element. This is not unexpected because it is seen as both inherent in self-employment and as a benefit of self-employment (European Commission, 2004); however, the findings do have implications for policies aimed at promoting entrepreneurship. Policies that help entrepreneurs cope with stressors unrelated to their employment might lead to entrepreneurship becoming a more attractive and positive 
experience. To deal with issues that entrepreneurs identify as problematic, such as government policy and culture, the lack of access to finance and insufficient family and community support might create a situation where self-employment is linked to even higher levels of wellbeing than wage-earning employment (Fielden \& Davidson, 2005). Together with policies aimed at facilitating non-standard work schedules and long work hours for those with family responsibilities, such as subsidised full-time and off-hours day care, this might also give considerable aid towards mitigating the negative job control-related effects of selfemployment on work-life balance. It is also important to design work for selfemployed men and women, making it possible for workers to balance different roles and to receive support from family and business networks.

Finally, this study has obvious limitations. There are concerns with analysing a dataset generated from multinational studies; consequently, the results should be interpreted with caution noting the following two limitations. First, the framing of the questions is context dependent, which indicates that certain questions might be understood and interpreted differently according to the national contexts. Second, differences in sampling, representativeness and response rates exist between the countries in this study. For instance, the response rates vary between countries from 44 percent in France to 79 percent in Greece. Thus, the responses are weighted according to the principles described on the ESS home page for 2004 (http://ess. nsd.uib.no/ess/round2/) to assure that the samples correspond to comparable statistical sources for each country. The resulting samples should therefore be nationally representative.

The fact that the levels of control and demands at work influence the relationship between the independent variable (the employment type) and the dependent variables (the work-life balance and wellbeing) point to the importance of these psychosocial work factors. However, one cannot exclude the possibility that other factors that are not included as control factors in this study, such as life style and other specific traits, might also be of more importance to research outcomes. Issues of causality are always problematic in cross-sectional studies. It is difficult to evaluate if the significant relationships are causal and what directions they take. In addition, the selfemployed are heterogeneous, and it is important to future research to study various groups of self-employed persons in relation to considerations, such as sector, enterprise size and individual factors. Conversely, the relatively large population sample from different countries enables a broad generalisation. The data set also has a reasonably high level of validity and reliability because it contains well-measured indicators.

\section{CONFLICT OF INTEREST AND FUNDING}

There is no conflict of interest among the authors.

\section{ACKNOWLEDGEMENTS}

The study was funded by the Swedish Research Council and Swedish Council for Working Life and Social Research. 


\section{REFERENCES}

Allvin, M., Aronsson, G., Hagström, T., Johansson, G., \& Lundberg, U. (2004). Gränslöst arbete-socialpsykologiska perspektiv på det nya arbetslivet [Work without boundaries: psychosocial perspectives on the new working life]. Malmö: Liber.

Andersson, P. (2006). Four essays on selfemployment (Doctoral thesis). Swedish Institute for Social Research, Stockholm, Sweden.

Benavides, F.G., Benach, J., Diez-Roux, A.V., \& Roman, C. (2000). How do types of employment relate to health indicators? Findings from the second European survey of working conditions. Fournal Epidemiology Community Health, 54, 494-501.

Bernin, P. (2002). Managers' working conditionsStress and health (Doctoral thesis). Karolinska Institutet, Stockholm, Sweden.

Blanchflower, D.G. (2004). Self-employment: More may not be better. Swedish Economic Policy Review, 11(2), 15-73.

Bornberger-Dankvardt, S., Ohlson, C.G., \& Westerholm, P. (2003). Arbetsmiljö-och hälsoarbete $i$ småföretag - försök till helhetsbild [Work environment and occupational health in small business - Seeking the full picture]. Work Life in Transition 2003:1, Stockholm: National Institute for Working Life.

Bradley, D.E., \& Roberts, J.A. (2004). Selfemployment and job satisfaction: Investigation the role of self-efficacy, depression, and seniority. Fournal of Small Business Management, 42(1), 37-58.

Chung, H. (2011). Work-family conflict across 28 European countries: A multi-level approach. In S. Drobnič \& A. M. Guillén (Eds.), Work-life balance in EuropeThe role of job quality (pp. 42-68). Chippenham and Eastbourne: Palgrave Macmillan.

Curran, J., \& Blackburn, R.A. (2001). Researching the small enterprise. London: SAGE.

Davidsson, P. (2005). Researching entrepreneurship. New York: Springer.

de Lange, A.H., Taris, T.W., Kompier, M.A.J., Houtman, I.L.D., \& Bongers, P.M. (2003). The very best of the Millennium: Longitudinal research and the demand- control-(support) model. Fournal of Occupational Health Psychology, 8(4), 282-305.

Dolinsky, A.L., \& Caputo, R.K. (2003). Health and female self-employment. Fournal of Small Business Management, 41(3), 233-241.

Eakin, J.M., Lamm, F., \& Limborg, H.J. (2000). International perspective on the promotion of health and safety in small workplaces. In K. Frick, P.L. Jensen, $M$. Quinlan, \& T. Wilthagen (Eds.), Systematic occupational health and safety management (pp. 227-247). Oxford: Elsevier Science.

European Commission. (2004). Action plan: The European agenda for entrepreneurship. Retrieved from http://europa.eu.int/comm/ enterprise/entrepreneurship/action_plan. htm

Fagan, C., \& Walthery, P. (2011). Job quality and the perceived work-life balance fit between work hours and personal commitments: A comparison of parents and older workers in Europe. In S. Drobnič \& A.M. Guillén (Eds.), Worklife balance in Europe-The role of job quality (pp. 69-94). Chippenham and Eastbourne: Palgrave Macmillan.

Fielden, S.L., \& Davidson, M.J. (2005). International handbook of women and small business entrepreneurship. Northampton, MA: Edward Elgar Publishing.

Fölster, S. (2000). Do entrepreneurs create jobs? Small Business Economics, 14(2), 137-148.

Gunnarsson, K. (2010). Entrepreneurs and small-scale enterprises: Self reported health, work conditions, work environment management and occupational health services (Doctoral thesis). Uppsala University, Uppsala, Sweden.

Grönlund, A. (2004). Flexibilitetens gränser: förändring och friktion $i$ arbetsliv och familj [The boundaries of flexibility: change and friction in working life and family] (Doctoral thesis). Umeå University, Umeå, Sweden.

Grönlund, A. (2007). More control, less conflict? Job demand-Control, gender and work-family conflict. Gender, Work E Organization, 14(5), 476-497. 
Harte, S. (1996, July 29). Women who work it out. Atlanta fournal Constitution, C1.

Henrekson, M., \& Stenkula, M. (2009). Entrepreneurship and public policy. Stockholm: Research Institute of Industrial Economics.

Hundley, G. (2001). Why and when are the self-employed more satisfied with their work? Industrial Relations, 40, 293-316.

Jamal, M. (1997). Job stress, satisfaction and mental health: An empirical examination of self-employed and nonself-employed Canadians. Fournal of Small Business Management, 35(4), 48-57.

Jonsson, D. (2007). Time-related fexibility and stability for employees. In B. Furåker, K. Håkansson, \& J.Ch. Karlsson (Eds.), Flexibility and stability in working life (pp. 197-217). New York: Palgrave Macmillan.

Karasek, R., \& Theorell, T. (1990). Healthy work: Fob stress, productivity and the reconstruction of working life. New York: Basic Books.

Lindström, K., Schrey, K., Ahonen, G., \& Kaleva, S. (2000). The effects of promoting organizational health on worker wellbeing and organizational effectiveness in small and medium-sized enterprises. In L.R. Murphy, \& C.L. Cooper (Eds.), Healthy and productive work-An international perspective (pp. 83-104). London: Taylor \& Francis.

Löwe, B., Spitzer R.L., Gräfe, K., Kroenke, K., Quenter, A., Zipfel, S., ... Herzoq, W. (2004). Comparative validity of three screening questionnaires for DSM-IV depressive disorders and physicians' diagnoses. Fournal of Affective Disorders, 78(2), 131-140.

Nordenmark, M. (2004a). Arbetsliv, familjeliv och kön [Working life, family life and gender]. Boréa: Umeå.

Nordenmark, M. (2004b). Does gender ideology explains differences between countries regarding the involvement of women and men in paid and unpaid work? International Fournal of Social Welfare, 13, 233-243.

Parasuraman, S., \& Simmers, C.A. (2001). Type of employment, work-family conflict and well-being: A comparative study.
Fournal of Organizational Behavior, 22, 551-568.

Rogers, N.E. (1998). The role of marital status, family composition, role commitment, family support of career and role conflict in women business owners' success (doctoral thesis). University of Cincinatti, Cincinnati, $\mathrm{OH}$.

Stephan, U., \& Roesler, U. (2010). Health of entrepreneurs vs. employees in a national representative sample. Fournal of Occupational and Organizational Psychology, 83(3), 717-738.

Sundin, L. (2009). Work-related social support, job demands and burnout: Studies of Swedish workers, predominantly employed in health care (Doctoral thesis). Karolinska institutet, Stockholm, Sweden.

The Swedish Social Insurance Inspectorate. (2012). Sjukfränvaro och vård av barn bland företagare. En analys av utvecklingen under 2000-talet [Sickness absence and care of children among self-employed: an analysis of development during the twenties century]. Stockholm: Author.

Theorell, T., \& Karasek, R. (1996). Current issues relating to psychosocial job strain and cardiovascular disease research. fournal of Occupational Health Psychology, 1(1), 9-26.

Vinberg, S. (2006). Health and performance in small enterprises: Studies of organizational determinants and change strategy (Doctoral thesis). Luleå Unviersity of Technology, Luleå, Sweden.

Volery, T., \& Pullich, J. (2009). Healthy entrepreneurs for healthy businesses: An exploratory study of the perception of health and well-being by entrepreneurs. New Zealand Fournal of Employment Relations, 35(1), 4-16.

Verheul, I., \& Wennekers, S. (2002). Entrepreneurship: Determinants and policy in a European-US comparison. Boston: Kluwer.

Wilkinson, A. (1999). Employment relations in SMEs. Employee Relations, 21(3), 206-217. 